\title{
Demokratisasi Desa dan Partisipasi Politik: Menurunnya Partisipasi dan Dukungan Warga dalam Pelaksanaan "Politik Lokal" di Bulungan-Pati
}

\author{
Ibnu Mujib \\ Program Studi Pendidikan Jasmani Kesehatan dan Rekreasi \\ IKIP Budi Utomo Malang \\ Jalan Simpang Arjuno 14 B Malang \\ ibnu_mudjib78@yahoo.com
}

\begin{abstract}
This study wants to keep track of public participation in responds to development of uncertaintly local democratic. This idea is based on an assumption of declining public participation in the previous elections of 2004. This study tries to observe how the development of democracy at the grassroots level can be influenced by extends political effect for imaging virtually designed and shaped by political pragmatism practices as conducted by the politicians in general. The findings of this study explained that the democratization at the level of village/local is not understood as an urgent need, therefore the political participation of society is still in the category of "anut grubyuk" participation profess that is not based on the ideals and demands the real political rights of citizenship. The forms of participation are thus precisely met the drying times of democracy itself. It means that the future death of village democratization not only addressed because of the laziness of residents to political participation, but the attitude of the political elite is also partly responsible, especially in negotiating the political choices to rural communities in general.
\end{abstract}

Keywords: village democracy, public participation, local politics, and citizen support, and political pragmatism

Pada dasarnya masyarakat desa adalah masyarakat yang bersifat egaliter (di Jawa dikenal dengan konsep sami-sami, padha-padha) (Suhartono, 1999). Secara historis masyarakat desa mengalami proses transformasi sosial sejak masa pra kolonial (zaman kerajaan), masa kolonial, Orde Lama, Orde Baru, hingga kini (sebut saja "Orde Transisi Menuju Demokrasi"). Pada masa colonial melalui system kekuasaan indirect rule partisipasi rakyat desa telah dibypassed guna melancarkan eksploitasi kolonial lewat penguasa lokal. Pemerintah kolonial telah menutup "partisipasi demokratis" rakyat desa dan mengubahnya ke bentuk "partisipasi kolektif-otoriter", yang mau tidak mau mengakibatkan rakyat harus tergantung pada perkebunan dan pemerintah.

Gejolak sosial-politik masyarakat desa pada era Orde Baru antara lain dapat dilihat dari peristiwa pemilihan kepala desa (Pilkades) [Fattah 1994] ${ }^{1}$. Penelitian yang dilakukan oleh Balai Penelitian Pers dan Pendapat Umum (BP3U 1988) menunjukkan bahwa penyebab munculnya gejolak dalam masyarakat desa saat diselenggarakannya Pilkades, antara lain:jumlah pemilih tidak memenuhi kuorum, calon tunggal tidak terpilih, calon favorit tidak lulus ujian tulis, calon tersangkut OT (organisasi terlarang), penghitungan suara dilakukan dua kali (secara terbuka dan secara tertutup), kelebihan suara pemilih (ada pemilih tidak sah), dan aksi boikot (sebagian pemilih sengaja tidak memberikan suaranya) [Kompas 1997].

Pada era reformasi, situasi desa ditandai oleh berbagai pergolakan politik menyangkut isu: pemilihan kepala desa (Pilkades), masalah penguasaan tanah, kasus tuntutan pencopotan jabatan (mulai dari kepala desa sampai bupati), munculnya semacam gerakan tandingan yang efeknya memecah-belah dan menggelisahkan masyarakat. ${ }^{2}$ Masyarakat desa menuntut para kepala desa beserta perangkatnya yang selama masa Orde Baru aktif membantu mengumpulkan suara untuk Golkar agar mengundurkan diri. Demikian pula kepada para camat yang dinilai telah melakukan tindak korupsi, kolusi, dan nepotisme (KKN) "dipaksa" oleh rakyat desa untuk melepaskan jabatannya (Soetrisno 1999). Selain itu, gejolak sosial rakyat desa makin meninggi sejak diimplementasikannya undangundang otonomi daerah pada Januari 2001. Respon masyarakat desa terutama difokuskan 
pada isu perubahan posisi dan fungsi pemerintahan desa, pemilihan anggota BPD, dan pengisian perangkat desa.

Di tingkat akar rumput, paling tidak ada tiga sikap yang berkembang dalam menanggapi implementasi UU No.22/1999, khususnya dalam hal pembentukan BPD. Pertama, kelompok masyarakat yang "menentang" dibentuknya BPD. ${ }^{3}$ Kedua, kelompok yang bersikap kritisskeptis, Ketiga, kelompok yang menyambut dengan antusias kebijakan pembentukan BPD.

Studi ini antara lain ingin melihat perkembangan perubahan demokratisasi masyarakat di akar rumput atau pedesaan, khususnya pada masyarakat Bulungan, Tayu, Kabupaten Pati. Selain juga dinamika politik lokal yang demikian kompleks merupakan gejala sosial-politik yang dapat dilihat sebagai bentuk demokratisasi dalam konteks pedesaan. Pada perkembangan itu masyarakat desa telah memiliki bentuk, ekspresi serta respon yang tentu berbeda dengan masyarakat perkotaan atau dikalangan masyarakat elit menengah. Tuntutan yang demikian baru ini juga sekaligus memunculkan persoalan yang tidak saja ditangggung warga sendiri tapi juga negara (the village becomes part of the state) (Hirsch 1989:1) di antaranya adalah partisipasi masyarakat di dalam proses demokratisasi. Belum lagi kesiapan warga serta dukungan sosial politik yang tidak stabil akan mengakibatkan minimnya respons publik terhadap proses demokratisasi itu sendiri.

\section{PROFILE BULUNGAN DAN PELUANG DEMOKRATISASI DESA}

Bulungan merupakan sebuah desa yang memiliki perubahan tingkat jumlah penduduk yang relatif cepat. Data paling terakhir menunjukkan bahwa Bulungan memiliki 3765 yang terdiri dari 1661 laki-laki, dan 1904 dihuni oleh perempuan. Secara administratif, penduduk desa Bulungan terbagi kedalam 3 RW dan $21 \mathrm{RT}$, pembagian yang demikian ini dapat dikategorikan sebagai penduduk yang relatif padat. Hampir $80 \%$ masyarakat Bulungan berprofesi petani, baik petani buruh, petani penggarap maupun pemilik tanah. Sementara $20 \%$ penduduk yang lain bekerja pada ranah guru, PNS dan pedagang.

Masyarakat Bulungan juga terhitung sebagai masyarakat homogin, perbedaan di tingkat etnis atapun agama tidak tampak di desa ini, paling hanya satu yang beragama selain Islam di desa ini (wawancara dengan pak Dzikron 20 Mei 2008). Bahkan dapat disebut bahwa masyarakat desa Bulungan memiliki basis islam tradisionalis yaitu NU. Namun secara politik mereka mengambil tempat atau posisi yang kadang berhadap-hadapan, meski di antara mereka komitmen komunalitas yang ia tunjukkan sebelumnya justru menjadi perekat atas perbedaan politik di kalangan elit lokal. Keharmonisan itu ditunjukkan oleh misalnya kedua tokoh partai yaitu antara pak Dzikron (PDIP) denganPakMuhammad Zain (PKB) samasama dari komunitas penghafal Quran mereka justru memiliki perbedaan pandangan politik yang tegas. Yang demikian ini menunjukkan bahwa komunalitas di pedesaan lebih mampu mendasari perbedaan antarkelembagaan politik yang ada.

Komunalitas masyarakat pedesaan Bulungan ini juga tampak pada bagaimana meraka menjaga kekompakan dalam merespon partisipasi dan dukungan sosial-politik di era demokratisasi desa yang demikian meluas ini. Warung-warung kopi yang ada di setiap pojok administrasi kewilayahan desa ini telah menjadi komoditi politik yang secara tidak disadari kelembagaan-kelembagaan sosial non formal ini justru dijadikan pusat berbagai informasi dan diskusi warga mengenai banyak hal, termasuk isu pergantian kepala desa. Menariknya, meski isu tersebut tidak secara terbuka diinformasikan ke publik, tetapi melalui ruang demikian ini kalangan akar rumput desa mengenali tipologi serta berbagai ciri calon kepala desa yang akan menjadi jago di desa mereka. Oleh karena itu, peran warung-warung kopi tidak saja sebagai tempat "leyeh-leyeh" (setelah pagi hari bekerja), tetapi juga sangat membantu melihat bagaimana proses sosial-politik masyarakat Bulungan disosialisasikan, khususnya sebagai penanda media tumbuhnya demokratisasi desa di tingkat lokal. Itu artinya tradisi oral telah mendominasi pilihan komunikasi politik masyarat di tingkat desa.

Potret demokratisasi desa di era 60-80 an, seperti di tunjukkan oleh Husken "Masyarakat Desa dalam PerubahanZaman" kebogedhemenang berike (Husken 1989:1). Selain dapat dilihat dari berbagai media di atas, demokratisasi desa juga dapat dilihat dari kelas sosial. Kelas sosial di desa Bulungan misalnya adalah bagian dari representasi kelas atau kelompok masyarakat berdasarkan setting ekonomi desa. Kekuasaan berarti juga kekayaan atau mereka yang menepati kelas sosial tertinggi. Yang demikian itu berarti bahwa kekuasaan selain diproduksi 
melalui relasi antarkelas sosial yang ada, ia juga digambarkan sebagai tokoh atau elit lokal yang merepresentasi kemenangan politik dan ekonomi. Oleh karena itu, kekuasaan di tingkat desa tidak dibentuk oleh pemaknaan masyarakat atas figur kepemimpinan yang dipilih dengan ukuran-ukuran atau kemenangan partai politik tertentu, tetapi figur kepeminpinan di desa diukur dari kapital yang dimiliki calon dan akses kapital bagi orang-orang yang ada di bawah kelas sosial calon. Itu artinya ketergantungan pemilih terhadap calon yang berkapital tinggi menjadi ukuran demokratisasi di tingkat desa.

Pada saat penelitian ini dilakuakan, demokratisasi Bulungan yang juga bagian dari konstruksi negara, tidak luput dengan terjadinya gesekan-gesekan sosial-politik khususnya di tingkat elit lokal Bulungan. Sebut saja misalnya, konflik kepala desa yang hingga hampir setahun terakhir ini belum menunjukkan tanda-tanda perbaikan. Kepala Desa yang konon diberhentikan karena habis masa kerja, hingga kini pemberhentian tidak diindahkan dengan baik olehnya, meski Bupati Pati telah mengangkat pejabat semantara yaitu Carik atau sekretaris desa. Namun karena belum ada serah terima jabatan dari kepela desa yang lama, kata Carik, maka melalui camat Tayu, surat pengangkatanPJS dikembalikan ke Bupati. Carik desa Bulungan yang sekarang melanjutkan studi setrata satu pada fakultas hukum di Malang itu mengatakan bahwa operasinal desa sementara di hendle oleh Carik, sedangkan kebijakankebijakan yang membutuhkan tandatangan langsung kepala desa tidak dapat dilakukan, termasuk urusan anggaran desa yang selama setahun terakhir ini-karena kasus itu-tidak dapat cair. Masih menurut carik desa ini, Bupati sebagai yang punya otoritas pengangkatan struktur di bawahnya, sampai detik ini belum melakukan tindakan apapun.

Konflik lokal yang demikian kompleks ini, di satu sisi secara tidak langsung telah menjadi pelajaran berharga bagi masyarakat desa, khususnya meningkatnya pendidikan politik di tingkat lokal. Namun di sisi lain, pendidikan politik yang demikian berharga ini justru menjadi beban psikologis bagi warga atau masyarakat terhadap peluang demokratisasi desa, demikian itu ditunjukkan oleh warga dengan menurunnya bentuk-bentuk partisipasi dan dukungan politik pada proses-proses politik belakangan ini. Oleh karena itu, konstruksi demokratisasi desa yang dikembangkan oleh negara tidak selalu memiliki dampak positif pada ranah lokal. Melainkan masyarakat pedasaan memilki cara dan expresi politik yang berbeda dalam berdemokratisasi. Sebut saja soal BPD (Badan perwakilan desa) yang dinilai gagal merawat demokratisasi di desa. Oleh karena itu, tidak heran jika perubahan pada tingkat fungsi dan bentuk BPD ikut menandai proses demokratisasi di aras lokal.

\section{PERGESERAN FUNGSI BPD LAMA KE BPD BARU}

\section{Sebuah Ruang Baru atau Kegagalan Demokratisasi Desa?}

Beberapa indikator penting yang menandai terbukanya ruang demokratisasi desa pasca reformasi di antaranya, pertama, pemisahan antarafungsieksekutif dan fungsi legislatif dalam pemerintahan desa. Fungsi eksekutif dijalankan oleh pemerintah desa, yang terdiri dari kepala desa dan perangkat desa, sedangkan fungsi legislatif dijalankan oleh Badan Perwakilan Desa (BPD). Kedua, Anggota dan pimpinan BPD tidak diperbolehkan merangkap jabatan sebagai kepala desa dan perangkat desa. Ketiga, dalam melaksanakan tugas dan kewajibannya kepala desa bertanggungjawab kepada rakyat melalui BPD. Keempat, Kepala desa yang bersikap dan bertindak tidak adil, diskriminatif dan mempersulit dalam memberikan pelayanan kepada masyarakat diberikan teguran dan atau peringatan tertulis oleh BPD. Kelima, Kepala desa dipilih langsung oleh penduduk desa, dan yang mendapat suara terbanyak ditetapkan oleh BPD dan disahkan oleh bupati. Keenam, Anggota BPD dipilih dari dan oleh penduduk desa. Ketujuh, BPD dapat mengusulkan pemberhentian kepala desa. Kedelapan, Pemerintah desa berhak menolak pelaksanaan tugas pembantuan yang tidak disertai dengan pembiayaan, sarana dan prasarana, serta sumber daya manusia. ${ }^{4}$

Aturan main yang ditata sedemikian detiil di atas tidak lain untuk mengawali sebuah babak baru konstruksi Negara atas tatanan demokratisasi di tingkat desa. Melalui aturan main ini, masyarakat di tingkat desa dituntut untuk ikut berpartisipasi dalam proses politik di desa, termasuk ikut menentukan kebijakankebijakan politik dan pemerintahan. Namun perlu diakui bahwa aturan main yang demikian lengkap itu tidak selamanya berproses sesuai dengan yang direncanakan atau yang diidealkan. Kasus pembentukan BPD misalnya, yang semula sebagai badan perwakilan desa atau sebagai lembaga legislatif pada tingkat desa dengan fungsi sebagai pengawas lembaga eksekutif desa, karena itu BPD dipilih langsung 
oleh rakyat desa sebagai bentuk perwakilan dari berbagai representasi lembaga atau struktur di bawah desa. Namun belum genap satu dasawarsa keberadaan BPD-yang dinilai ideal untuk demokarasi desa - kini sudah mengalami perubahan fungsi, bahkan keberadaanya tidak lagi sebagai lembaga perwakilan desa, tetapi sudah menjadi lembaga atau Badan Permusyawaratan Desa. ${ }^{5}$

Dengan bergesernya fungsi dan bentuk kelembagaan legeslatif desa ini, maka itu artinya semangat demokratisasi desa di satu sisi telah mengalami kegagalan proses-proses demokrasi, di mana sebuah badan atau lembaga yang seharusnya berfungsi sebagai pengawas lembaga exekutif desa, kini berubah menjadi badan yang tidak memiliki kekuatan dan otoritas yang sama. Namun di sisi lain pergeseran itu bisa jadi merupakan pilihan expresi atau pola yang memang dikehendaki oleh masyarakat di akar rumput atau desa. Oleh karena itu, dengan basis komunalitas yang kuat di desa, seperti semangat gotong royong, lebih mengutamakan harmonis atau rukun dari pada konflik, lebih-lebih istilah "mangan ora mangan sing penting ngumpul", maka sangat rasional bila pergeseran fungsi dan bentuk kelembagaan itu terjadi. Pernyataan ini didukung oleh Carik desa Bulungan yang mengaku bahwa banyak pengurus BPD belum memahami substansi aturan main BPD sendiri, sehingga yang terjadi justru saling curiga, bahkan konflik. (wawancara dengan Carik Bulungan, 20 Mei 2008), meski pernyataan tidak senada dipertanyakan oleh salah satu pengurus BPD Bulungan.

Basis social yang demikian kuat itu tidak lain adalah konstruksi budaya (cultural construction) masyarakat desa, di mana desa sebagai sebuah institusi social yang kuat tentu memiliki sistem sendiri, yang berbeda dengan system yang ada di luar desa. Oleh karena itu, kebijakan apapun yang terkait dengan masalah pedesaan harus memiliki akar kebudayaan yang kuat. Hal senada diungkap secara sepontan oleh salah satu pengurus PKB Bulungan, bahwa "demokratisasi" di dalam konteks desa belum bisa dirasakan manfaatnya oleh masyarakat desa, karena itu kadang sistem demokrasi tidak cocok untuk masyarakat di tingkat lokal (Wawancara dengan tokoh agama sekaligus pengurus PKB Bulungan Bpk. Muhamad zain).

Sejalan dengan hal itu, "Proyek" demokratisasi desa perlu diakui masih berada dalam status "demokrasi formal/ prosedural". Ini artinya posisi gerak demokratisasi desa masih berada pada tahap awal. Ada dua hambatan yang segera muncul pada titik ini. Pertama, kenyataan landasan formal (UU No.22/1999) demokrasi desa baru diberlakukan secara efektif beberapa tahun terakhir ini. Kedua, terputusnya proses pendidikan politik rakyat desa dalam rentang waktu yang cukup lama (usia satu generasi, 1966-1998) menjadikan kondisi kognitif dan emosi rakyat desa nyaris tak berdaya dalam urusan partisipasi politik. ${ }^{7}$ Oleh karena itu, perlu upaya keras dan sungguh-sungguh untuk meningkatkan keberdayaan politik rakyat desa.

Termasuk lahirnya "otonomi desa" juga setidaknya dipicu oleh aspek sosial budaya, seperti rakyat desa mengalami kesenjangan sosial yang kian meluas, merenggangnya solidaritas sosial, bergesernya orientasi hidup pada halhal yang bersifat material (segala sesuatu mulai diukur dengan uang), dan juga mengalami apa yang saya sebut sebagai "kelambanan sosial" (social inertia). Gejala kelambanan sosial ini ditandai (dan disebabkan) oleh sulitnya penduduk desa melakukan usaha atau bekerja di desa, sehingga mengakibatkan keputusasaan (hopelessness) (Kartodirdjo 1987:221); di samping itu secara sosial politik mengalami keengganan, kemalasan, ketidakpedulian, dan akhirnya ketakutan menghadapi dan menanggapi isu-isu sosial politik yang berkembang di sekitarnya.

\section{Partisipasi Politik dan Dukungan Masyarakat Bulungan}

Prinsip dasar suatu kehidupan yang demokratis ialah tiap warga negara ikut aktif dalam proses politik. Dengan kata lain, anggota masyarakat ikut serta (partisipasi) dalam menyusunagendapolitikyangdijadikanlandasan bagi pengambilan keputusan pemerintah. Demokrasi bisa berjalan jika masyarakat sadar bahwa mereka memiliki hak untuk mengontrol jalannya pemerintahan. Demokrasi baru bisa berjalan kalau pencapaian tujuan-tujuan dalam masyarakat diselenggarakan oleh wakil-wakil mereka (representative government), yang dibentuk berdasarkan hasil pemilihan umum (Antlöv 2002: 43). Prinsip dasar pelaksanaan demokrasi di Indonesia ialah "musyawarah untuk mufakat". Prinsip musyawarah mengandung dimensi proses ("demokrasi substansial"), sedangkan prinsip mufakat mengandung dimensi tujuan ("demokrasi formal"). Dalam praktik, pelaksanaan demokrasi di Indonesia lebih menitikberatkan pada pencapaian tujuan (aspek formalitas demokrasi) ketimbang 
pada proses pencapaiannya (aspek substansi demokrasi). Dari sisi status demokrasi, "proyek" demokratisasi desa jelas baru masuk pada tahap "demokrasi formal" (Djadijono 1994:31).

Demokratisasi formal desa di Bulungan tampak pada bagaimana masyarakat menyikapi dukunganya pada pemilihan umum 2004 misalnya. Ketika pilihan politiknya gagal merumuskan kebutuhan masyarakatnya, artinya pemerintah tidak merespon kebutuhuan dasar masyarakat pemilih, maka logika politik masyarakt desa berbalik 180 derajat yaitu dengan mengimbangi sikap politik elit, yaitu dengan malas-malasan terlibat proses politik di desa. Demikian itu tampak pada menurunnya partisipasi masyarakat desa pada pemilihan umum presiden 2004. Tidak kurang dari 95\% perserta pemilih ikut dalam partisipasi politik pemilihan presiden 1999. Tetapi hampir 45\% masyarakat pemilih tidak menggunakan hak pilihnya, dengan alasan bahwa keterlibatanya hanya ketika para elit membutuhkan dukungan saja, ungkap salah satu pemuda Bulungan (Yudi 20 tahun). Ungkapan itu dibenarkan oleh carik Bulungan yang mengatakan bahwa pada pemilu 2009 lalu masyarakat Pati pada umumnya tergolong memiliki tingkat partisipasi politik paling rendah dibanding kabupaten-kabupaten yang ada di Jawa tengah lainya. Tabel di bawah ini memperlihatkan bagaimana masyarakat desa Bulungan berpartisipasi dalam pemilihan umum. muda, baik dengan cara golput (golongan Putih), merusak kertas suara, maupun tidak terlibat sama sekali dalam pemilu. Pernyataan serupa diakui pula oleh pak Dzikron yang juga ketua PDIP Bulungan menyatakan bahwa gairah partisipasi masyarakat terhadap pemilu 19992009 tinggi, tapi pada pemilu 2009 partisipasi warga menurun dan itu ditunjukkan bahwa angka perolehan PDIP menurun. Pernyataan pak Dzikron dan Yudi ketika di warung Bu Supinah Bulungan ini tidak saja menandai lemahnya partisipasi politik warga, tetapi bahwa demokratisasi desa baru diimplementasikan sebatas formalitas aturan main demokrasi, di mana substansi demokrasi desa masih belum dirasakan manfaatnya. Kerianggembiraan kolektif warga dalam demokratisasi desa hanya ditunjukkan secara formalitas sebagai bagian dari tuntutan Negara atas masyarakat di tingkat desa. Demokratisasi belum dipahami oleh masyarakat desa sebagai kebutuhan yang urgen, karena itu partisipasi politik masyarakatpun masih dalam kategori partisipasi "anut grubyuk" (ikut-ikutan).

\section{Pragmatisme Politik Anak Muda dan Politik "Dorong Mobil"}

Pernyataan di kalangan anak muda Bulungan khususnya tentang politik lokal adalah merupakan bagian dari pembicaraan atau kojah warungan hari-hari. Baik mengenai politik lokal,

Tabel 1 Partisipasi Masyarakat dalam Pemilu 2009 Desa Bulungan-Tayu-Pati

\begin{tabular}{lcccc}
\hline \multicolumn{4}{c}{ Masyarakat yang Tidak Menggunakan Hak Pilih } & Suara tidak sah \\
\hline Representasi TPS & Laki-laki & Perempuan & Jumlah & \\
TPS I & 40 & 23 & 63 & 4 \\
TPS II & 30 & 19 & 49 & 2 \\
TPS III & 46 & 23 & 69 & - \\
TPS IV & - & - & - & - \\
TPS V & 39 & 32 & 71 & 5 \\
TPS VI & 28 & 21 & 49 & 17 \\
TPS VII & 26 & 25 & 51 & 3 \\
TPS VIII & 46 & 24 & 70 & 9 \\
Jumlah & & & $\mathbf{4 1 2}$ & $\mathbf{4 7}$ \\
\hline
\end{tabular}

Tabel di atas menggambarkan bahwa dari total pemilih 2459 orang, 412 orang pemilih tidak menggunakan haknya. Menurut pernyataan beberapa pemuda dan pejabat di Bulungan, pemilu 2009 adalah pemilu yang tidak banyak diikuti oleh warga Bulungan, khususnya anak partai politik, hingga hubungan antara wong sugih (mewakili kelas ekonomi elit) dan wong cilik (kelas sosial di bawahnya). Warung "kopi" di desa Bulungan tidak saja sekedar tempat orang jual beli kopi cangkiran yang sehabis minum lalu pergi, tatapi warung kopi hampir di beberapa 
tempat di desa Bulungan selalu menandai ekxpresi, pola hidup, informasi, bentuk-bentuk representasi kelas lokal serta hubungan timbal balik antarkelompok juga terjadi di komunitas warung itu. Sebut saja misalnya warung pak Hartolo, menurut tutur beberapa orang warga desa Bulungan, warung ini kerap kali menjadi tempat ngobrol bidang "politik", bahkan ada salah satu warga yang tidak mau pergi ke warung itu hanya dengan alasan bicaranya (ngobrolnya) banyak mengenai politik. Oleh karenaitu warung pada tingkaat tertentu menjadi tempat curhat politik sekaligus pendidikan politik warga yang secara pelan tapi pasti akan menumbuhkan semangat demokratisasi arus bawah. Beberapa orang -pada saat wawancara dilakukan-- yang kerap kali janggol di warung ini antaralain: pak Joyo Supardji, Maduri, Matsuri dll. Bahkan warung secara umum juga tempat bertemunya lapisan kelas sosial yang kadang tidak bisa bertemu dalam satu forum khusus, mereka ada yang dari kelas wong cilik, ada juga yang dari kalangan guru PNS.

Situasi yang demikian itu setidaknya menggambarkan bagaimana masyarakat Bulungan dalam kelas tertentu menunjukkan pemahaman atau setidaknya memiliki cara sendiri dalam mensosialisasikan makna politik dalam kelas desa. Oleh karena itu tidak heran jika profokasi-profokasi politik di tingkat lokal mempengaruhi kelas-kelas sosial yang lain, bahkan warung juga menjadi mediasi perluasan implementasi perkembangan politik praktis yang sangat subur.

Berkaitan dengan hal ini, sebagai bentuk sosialisasi politik masyarakat desa Bulungan adalah sikap pragmatisme anak muda yang dinilai bagian dari proses demokratisasi di desa. Logika politik yang sederhana akan menjadi ukuran bagaimana di tingkat anak muda lokal mendeskripsikan expresi politiknya. Seperti yang ditegaskan Yudi (20 thn) bahwa dia sekarang tidak mau ikut-ikutan politik, dia malas karena seringkali dibohongi oleh para politisi. Pada saat kampanye, mereka janji akan memberi uang, tetapi ternyata setelah dukungan politik diberikan, ternyata tidak jadi diberi uang entah dengan alasan itu lah, bangkrut lah (wawancara dengan Yudi juga pak Joyo), lanjut Yudi mereka malah sudah tidak lagi mengenal kita, masih kata Yudi dan Prasetyo, ikut politik atau nyoblos pemilu samahalnya dengan disuruh dorong mobil, yang habis dorong orangnya pergi. Begitulah pelajaran politik yang diberikan elit kepada masyarakat bawah, yaitu pembohongan yang luarbiasa dilakukan para elit yang tidak mengenal bagaimana masyarakatnya memilki cara bernegosiasi politik sekaligus tidak memikirkan masadepan demokratisasi di tingkat lokal menemui kamatiannya.

Expresi serupa juga muncul dari Mas Waloyo (warga Bulungan yang biasa menjadi buruh tani di desa ini). Ungkap Mas Waloyo mengenai isu politik, dia lebih memilih untuk tidak terlibat dalam pelaksanaan proses politik di desanya, itu artinya mas Waloyo tidak ikut dalam proses pemilihan, baik pilpres, pilkada (bupati) maupun pilihan politik yang lain. Alasannya, daripada ia konflik dengan teman sekerjanya, lebih baik ia tidak berafiliasi dengan partai politik apapun. Sebab memilih pilihan politik berarti membuat kelompok atasnama politik, dan itu artinya ia harus melepaskan pertemanan yang selama ini dibangun. Oleh karena itu, di sinilah makna dan perwujudan bahwa komunalisme desa lebih mampu mendasari sikap politik di suatu imagi politik masyarakat tertentu, daripada kelompokkelompok atau institusi-institusi politik baru yang belum bisa dirasakan manfaatnya secara pragmatis oleh kelas tertentu.

Keengganan berpolitik masyarakat desa Bulungan merupakan fenomena baru pasca bebeberapa kali pemilu atau pilkada di lakukan di desa ini. Masing-masing kelas sosial memiliki cara yang berbeda dalam merespon demokratisasi desa termasuk pilihan-pilihan politik masyarakat di tingkat lokal. Jika terjadi kemunduran demokratisasi di pedesaan, itu bukan saja karena sistem demokratisasi yang ditawarkan tidak sesuai dengan mekanisme komunitas di pedesaan, tetapi tingkah atau sikap elit politik yang tidak fair dalam menegosiasikan pilihan-pilihan politik kepada publik juga dinilai akan merusak spirit demokratisasi dalam konteks masyarakat desa.

\section{KESIMPULAN}

Gambaran kekuasaan di tingkat desa tidak dibentuk oleh pemaknaan masyarakat atas figur kepemimpinan yang dipilih dengan ukuranukuran atau kemenangan partai politik tertentu, tetapi figur kepeminpinan di desa diukur dari kapital yang dimiliki calon dan akses kapital bagi orang-orangyang ada di bawah kelas sosial calon. Itu artinya ketergantungan pemilih terhadap calon yang berkapital tinggi menjadi ukuran demokratisasi di tingkat desa. Memetakan desa -kota dalam konteks politik dan demokrasi tidak berarti sama sekali melibatkan perdebatan teoritis yang strik, malainkan Desa ataupun 
kota dalaam konteks demokrasi ini seharusnya tidak dibangun atas dasar politik.

Ruang demokratisasi desa di Bulungan juga bisa kita lihat pada arena politik konflik kepala desa yang demikian kompleks itu. Oleh karena itu, di satu sisi secara tidak langsung telah menjadi pelajaran berharga bagi masyarakat desa, khususnya meningkatnya pendidikan politik di tingkat lokal. Namun di sisi lain, pendidikan politik yang demikian berharga ini justru menjadi beban psikologis bagi warga atau masyarakat terhadap peluang demokratisasi desa, demikian itu ditunjukkan oleh warga dengan menurunnya bentuk-bentuk partisipasi dan dukungan politik pada proses-proses politik belakangan ini. Basis sosial yang dimiliki desa ("akar komunalisme desa") harus dilihat sebagai landasan kebijakan dalam melihat gagal tidaknya sebuah demokratisasi di desa. Sebagai contoh pergeseran fungsi dan wewenang BPD, seharusnya tidak saja dinilai sebagai bentuk-bentuk kegagalan demokratisasi desa, tetapi keberadaan BPD-sebagai konsep yang dikonstruksi dari bentuk demokratisasi secara global- memeng perlu dilakukan evaluasi. Terlebih, pilihan BPD baru merupakan pilihan warga yang jauh dari bentuk-bentuk gesekan sosial baru yang akan berujuk pada konflikkonflik komunal.

Oleh karena itu, demokratisasi desa baru diimplementasikan sebatas formalitas aturan main demokrasi, di mana substansi demokrasi desa masih belum dirasakan manfaatnya. Kerianggembiraan kolektif atau partisipasi warga dalam demokratisasi desa hanya ditunjukkan secara formalitas sebagai bagian dari tuntutan Negara atas masyarakat di tingkat desa. Demokratisasi belum dipahami oleh masyarakat desa sebagai kebutuhan yang urgen, karena itu partisipasi politik masyarakatpun masih dalam kategori partisipasi anut grubyuk yang tidak dilandasi oleh idealisme dan tuntutan hak sipil kewargaan yang sesungguhnya. Masa depan demokratisasi desa yang seharusnya ditunjukkan melalui bentuk-bentuk partisipasi masyarakat, khususnya anak muda, di dalam konteks desa justru menemui ajalnya. Kematian masa depan demokratisasi desa tidak saja dialamatkan kepada malasnya warga terhadap partisipasi politik, tetapi sikap elit politik juga harus bertanggungjawab, khususnya dalam menegosiasikan pilihan-pilihan politik kepada masyarakat desa secara umum.

\section{DAFTAR RUJUKAN}

Antlöv,H. 2002. “Epilog 2002: Warisan OrdeBaru dan Tumbuhnya Demokrasi Lokal", dalam Negara Dalam Desa: Patronase Kepemimpinan Lokal. Yogyakarta: Lappera Pustaka Utama.

2003. "Village Government And Rural Development In Indonesia : The New Democratic Framework", Bulletin of Indonesian Economic Studies, Vol. 39, No. 2:193-214.

Balai Penelitian Pers dan Pendapat Umum (BP3U). 1988. Analisis Isi Surat Kabar Isu Sentral Bulan Juni 1988 di D.I. Yogyakarta dan Jawa Tengah: Pemilihan Kepala Desa. Laporan Penelitian. Yogyakarta: BP3U Deppen.

Data survey dan wawancara di Bulungan, Tayu, Pati, mulai taggl 19, 20, 21 Mei 2009. Narasumber, Pak Dzikron, Pak Muhammad Zain, Mas Yudi, Mas Waloyo, Mas Prass, Bu Darti, Pak Carik, Bu Carik, pak Joyo Supardji, Mas Maduri, Mas Matsuri dll dan tentunya 4 sekawan.

Djadijono, M. 1994. Arus Bawah Dalam Dinamika Kehidupan Politik di Indonesia. CSIS Occasional Papers Series, M116.

Eep, S.F. 1994. “Unjuk Rasa, Gerakan Massa dan Demokratisasi: Potret Pergeseran Politik Orde Baru". Prisma, No.4, XXIII, April.

Hirsch, P. 1989. "The State in the Village: Interpreting Rural Development in Thailand". Development and Change, Vol. 20 (1).

Hüsken, F. 1989. Masyarakat Desa dalam Perubahan Zaman, Sejarah Diferensiasi Sosial di Jawa 1830-1980.

2001. "Pemilihan (Kepala Desa, pen) di Desa di Jawa Tengah: Kendali Negara atau Demokrasi Lokal ?", dalam Hans Antlöv dan Sven Cederroth penyunting), Kepemimpinan Jawa: Perintah Halus, Pemerintahan Otoriter. Jakarta: Yayasan Obor.

Kartodirdjo, S. 1987. “Transformasi Struktural di Pedesaan: Beberapa Pokok Permasalahan", dalam Prospek Pedesaan 1987, P3PK UGM.

Kuntowijoyo. 1990. "Perubahan Sosial dan Budaya Politik : Prospek Demokrasi 
24 | Ibnu Mujib, Demokratisasi Desa dan Partisipasi Politik: ...

di Pedesaan", dalam Mubyarto dkk., Prospek Pedesaan 1990. P3PK UGM.

"Pemilihan Kepala Desa: Kepentingan Birokrasi atau Pengembangan Demokrasi". Kompas, 14 Desember 1997.

"Reformasi di Jawa: Kebangkitan Rakyat Pedesaan". Kompas, 24 Desember 1998.
Soetrisno, L. 1999. “Current Social and Political Conditions of Rural Indonesia", dalam Geoff Forrester (ed.), Post-Soeharto Indonesia : Renewal or Chaos ? Singapore, Institute of Southeast Asian Studies.

\section{(Endnotes)}

1 Eep Saefulloh Fatah (1994) mencatat bahwa periode akhir 1980-an adalah "periode awal keterbukaan politik", yang ditandai oleh banyaknya aksi demonstrasi dan protes yang dilakukan oleh buruh, kaum muda, mahasiswa, kalangan LSM serta komunitas masyarakat desa dan kota yang terpinggirkan oleh pembangunan.

2 Bagi masyarakat desa, era reformasi dilihat sebagai suatu eforia besar. Rakyat pedesaan yang sekian lama merasa tertekan mendadak merasa memegang kedaulatan, dan bangkit menuntut apa yang menurut mereka menjadi haknya, menentang atau menuntut perubahan kebijakan yang menurut mereka tidak adil atau merugikan. Lihat "Reformasi di Jawa : Kebangkitan Rakyat Pedesaan". Laporan koresponden Kompas dari berbagai daerah. Ibid.

3 Seorang guru SMP di Bulungan berpendapat bahwa pendirian BPD hanya akan menimbulkan suasana "gontok-gontokan" di desa. Oleh karena itu, dengan nada sinis, ia tidak sepakat dengan pendirian BPD (badan Perwakilan Desa) yang dulu. BPD lebih efektif dengan perannya yang sekarang (Badan Permusyawaratan Desa) Wawancara dengan pak Supardji, 21 Mei 2008. Pernyataan serupa diperkuat oleh Carik desa Bulungan yang juga mengungkapkan BPD format lama telah kehilangan fungsi semula, yang terjadi justru konflik wawancara, 21 Mei 2010.

4 Sumber : Himpunan Lembaran daerah Kabupaten Pati tentang pemerintahan Desa tahun, 2001.

5 Fungsi dan wewenang BPD (Badan Permusyawaratan Desa) dijelaskan dalam Himpunan Lembaran Daerah Kabupaten Pati tentang pemerintah desa tahun 2007. Adapun fungsi BPD kali ini membahas rancangan peraturan desa bersama kepala desa, melaksanakan pengawasan terhadap pelaksanaan peraturan atau keputusan kepala desa, mengusulkan pengangkatan dan pemberhentian kepala desa, membentuk panitia pemilihan kepala desa, menggali, menampung, menghimpun, merumuskan dan menyalurkan aspirasi masyarakat, dan menyususn tata tertib BPD.

6 Istilah ini merupakan prinsip hidup sebagian besar masyarakat jawa, meski tidak semua kelas social memakai logika ini, termasuk masyarakat yang ada di wilayah perkotaan.

7 Dengan merujuk pada sejarah pedesaan surakarta, kuntowijoyo berpendapat bahwa perkembangan pendidikan politik di pedesaan terputus secara tiba-tiba (akibat peristiwa G-30-S PKI 1965), sebelum mencapai tujuannya yaitu terciptanya sebuah "masyarakat yang berkeadaban" (civic culture). tiba-tiba saja sejarah politik terputus. sebagai akibatnya, keterlibatan politik secara massal di masa lalu (orientasi komunal) digantikan oleh keterlibatan para elit desa saja (orientasi subjek-elitis). hanya pada saat-saat menjelang pemilihan umum, masyarakat mengenal (dan mengenang) kembali partisipasi politik mereka. terjadi pergeseran bentuk partisipasi politik, dari yang semula berorientasi komunal (parochial-participant political culture) berganti orientasi pada subjek tertentu atau elit desa/ negara saja (subject-participant political culture). akibat lebih lanjut dari terjadinya pergeseran orientasi politik masyarakat desa ini ialah munculnya birokrasi (mewakili kekuatan negara yang amat dominan) yang memainkan peran yang amat penting dalam kehidupan politik di tingkat desa. birokrasi desa beserta elit birokrasi desa yang pada masa pra-1965 diremehkan oleh partai-partai politik di tingkat desa (karena dikalahkan oleh pengaruh pimpinan partai politik di tingkat desa), namun setelah 1965 kembali memegang peranan yang penting (lihat Kuntowijoyo 1990:59-60. 